\title{
ENDOGENOUS CONVERGENCE AND INTERNATIONAL TECHNOLOGICAL DIFFUSION CHANNELS
}

Josip Tica, Luka Šikić

\section{ABSTRACT}

The goal of the paper is to estimate relative importance of channels of technological diffusion between new member states and core EU countries. Based on neoclassical growth theory and extensive literature survey on technological diffusion we explore movements in the relative TFP in EU member states and try to identify relative importance of channels of technological diffusion as suggested by theory: imports, exports, FDI, R\&D, human capital and fixed capital formation, etc. In the first step we employ Phillips and Sul (2007) log t test which has power to detect convergence even in the absence of cointegration between time series. In the second part we employ Abrigo and Love (2016) PVAR model in order to detect channels of diffusion of technology. The data is sampled from Eurostat and PWT repository and covers the period from 1995-2016 for panel analysis and 1950-2014 for TFP convergence analysis. Our results indicate that in the overall sample FDI and $R \& D$ are major drivers of technological change, while, contrary to conventional wisdom, trade openness and human capital are dominant channels for TFP diffusion in periphery countries. The overall results point that productivity gap reduction is a heterogeneous process, country specific problem, but on average in the periphery it can be supported through various economic policies focused on openness and human capital.

Key words: TFP, channels of diffusion, convergence

JEL Codes: $F 43,047,033$

\section{INTRODUCTION}

It is well recognized that differences in productivity levels explain a significant portion of international income per capita variation and that technology is one of the main determinants of productivity levels (Hall and Jones 1999). Expanding technology levels is possible either through the autonomous technology creation that is usually related to $\mathrm{RnD}$, or some sort of technology transfer. Since most of the technology creation happens in developed and rich countries, the international diffusion of technology plays a major role for technology absorption in developing countries and transition economies. This finding is confirmed
Josip Tica, PhD

Full Professor

University of Zagreb

Faculty of Economics and Business

E-mail: jtica@efzg.hr

Luka Šikić, PhD

Institute of Social Sciences Ivo Pilar

E-mail: luka.sikic@pilar.hr 
by the large body of theoretical and empirical literature on the topic of international technology transfer (Keller 2009) where majority of evidence suggests that FDI and international trade serve as major channels of international technology diffusion.

Technology is considered to be one of the major determinants of (economic) performance at the firm, industry or aggregate level. This finding has received a wide empirical support in the growth literature. However, not much technology is created in a wide cross section of countries, probably due to resource, infrastructural and institutional constrains on the innovation process. Since creation of new technology only occurs in a small number of very rich countries, the developing countries can benefit that process if technology successfully diffuses across countries.

The aim of this analysis is to identify channels of international technological transfer and investigate how they affect the reduction of the productivity gap relative to the technological frontier in the sample of EU countries. The dominant focus is on European transition countries as they do not create a lot of technology within the local economy but rather through the technology transfer with the rest of European Union (Merikll et al. 2013). Taken the complexity of the convergence process of European transition countries, we contribute the debate on the transfer of technology by investigating how several most important channels of technological diffusion affect the reduction of productivity gap relative to the European Union. Furthermore, we try to account for the role of absorption factors in our empirical model whenever data allows for that.

We employ innovative methodological approach. First, using Phillips and Sul (2007) log t test we try to endogenously determine convergence clubs within $\mathrm{EU}$ and in the second step we use Abrigo and Love (2016) PVAR model in order to investigate channels of technology transfer between EU members and within and between endogenously identified convergence clubs. Here we use trade (exports and imports), FDI as international channels as well as several proxies for absorptive capacities to account for domestic technology transmission channels. Our approach allows for identification of causality direction between cointegrated variables, i.e. convergence clubs, and variables assumed to serve as channels of technology transfer, which has implication for economic growth.

The main empirical difficulty in the analysis of technology stems from difficulties related to measuring technology and similar variables. Several measures on the aggregate and disaggregate level have been used in the literature (Keller 2004). Usually, R\&D expenditure serves as a proxy for technological intensity but this measure may misrepresent the technological process since many $R \& D$ projects fail or technology gets discovered outside of $R \& D$. Furthermore, R\&D data is not available for a wide cross section of countries. The other frequently used measure of technology is the number of registered patents, probably due to the good data availability and relatively long time series. On the down side, there is a significant variation in the quality and value of patents so estimations based on that data might be biased. Also, some important new technological breakthroughs might not be patentable which reduces reliability of patents as a technological proxy.

On a broader level, changes in a country's or firm's productivity are also used as derived measures of technology (Keller 2009) since there is a wide consensus about the importance of technology for increasing the productivity. TFP based measures are easily available for a large sample of countries and firms but on the downside, they potentially contain a wide and non-identifiable set of factors not exclusively related to the technological process. In this analysis we follow the TFP based measure of technology where the reduction of the productivity gap relative to the technological frontier (Nelson and Phelps 1965) approximates the intensity of international technological transfer. Innovation and technology raise productivity through new goods and improvement of existing goods, implementing new organizational structures and processes, raising institutional quality and improving legal framework. In a wider sense, the productivity gap reduction will therefore capture the improvement of the countrys technological capacity.

The source of disagreement in the literature on technology transfer dominantly stems from the empirical side of the analysis. The first empirical problem is the measurement of variables of interest like technology or absorptive capacity. Many authors rely on the industry specific measures of technological capacity or assume that firms can access foreign technology equally (Blalock and Gertler 2008; Javorcik and Spatareanu 2008) which can be a restrictive assumption. Since different authors use different measures, the overall results are not directly comparable. The problem with absorptive capacity measures is mainly related to the commonly used productivity gap measures that are prone to the measurement error due to the fact that productivity gap can be affected by the shocks that are not related to the absorptive capacities of the firm (Girma and Grg 2007). Some studies (Ottaviano and Mayer ated; Nicolini and Resmini 2010) also pointed to the problem of differences in methodology used to study technological transfer and respective lack of comparability across different studies. 
The issue stays mainly unresolved, especially since many of the papers surveyed rely on different data sets, making mutual comparison even more difficult. The second empirical problem is related to the difficulty of drawing general conclusions about the technological transfer across different papers mainly because channels of technological diffusion are analyzed separately. For example, most papers on FDI and productivity analyze how direct investments affect productivity through spillovers but do not take the role of international trade into account (Keller 2004). On the other side, trade studies analyze productivity without taking FDI into account so the comparative evidence is missing, especially taken that firms often engage in these activities simultaneously. The difficulties related to the empirical analysis also stem from the fact that there might be a significant number of other factors that influence technological transfer other than international exposure through FDI and trade and might even have negative effects (Harrison and Aitken 1999). Finally, it is hard to sort out the causality between participation in the international activity and productivity and evidence does confirm that most productive firms might self-select into exporting (Melitz 2003).

Technological transfer is a complex process happening through multiple formal and informal channels. Part of the technological transfer happens through voluntary transactions but a significant amount occurs through non-market transactions and different spillovers. This creates further measurement issues and makes formal analysis somewhat difficult. Some of the major channels of technological transfer robusltly recognized in the literature are international trade and FDI flows. Trade of goods and services contributes to the technological capacity of a country through reverse engineering, learning about production methods and designs but also through effects on the market structure and organization of production. These effects are most obvious in the imports of capital and intermediate goods but exports also serve as an important channel of technological transfer, for example through contacts of sellers with buyers.

FDI, after trade, is the second major channel of technology transfer of advanced or new technology from the host firm to the subsidiary. The technological firm level spillovers that happen in that process are expected to benefit the aggregate economy as well. Other channels recognized in the literature include licensing, joint ventures and movement of (skilled) workers whereas the effects of them might also be interdependent. Big part of technological transfer happens unofficially and includes imitation, international movement of employed persons, university exchange or unofficial patent applications which are all difficult to measure and account for. The interdependence between formal and informal channels further increases the measure and identification issues.

Given the host of methodological problems in the analysis of technological transfer, most of the empirical work has focused on particular channels and in that sense disregards the full structure of the process. We tend to fill this gap in the literature by examining several of the most important channels of technological transfer within the coherent analytical framework. Although there is significant empirical literature on the topic of international technology transfer and productivity convergence, our motivation is related to the mixed evidence on this topic (Grg and Greenaway 2004) as well as lack of evidence on the relative importance of different channels of diffusion (Keller 2004). The main contribution of the paper is that it analyzes main channels of technological transfer in coherent new innovative methodological framework and within the converging and non-converging group of countries. In the Section 2 we provide literature review, in the section 3 data and methodology is presented and in the last two sections present results and conclusions.

\section{LITERATURE REVIEW}

Even though the theoretical literature (Markusen and Venables 1999; Grg and Greenaway 2004; Coe and Helpman 1995; Greenaway and Kneller 2007) is well developed and the empirical evidence on the topic of technology transfer is very large, much of this literature is ambiguous and hard to generalize upon. Best literature surveys on topics of international technological transfer through both trade and FDI are Keller (2004, 2009), through FDI are Barba Navaretti and Venables (2006) and Greenaway and Kneller (2007) whereas Wagner (2007) focuses on the trade. Generally, the evidence supports the idea that FDI is an important channel for international technological transfer. There is a good amount of evidence also pointing that trade, especially imports are a significant channel of international technology diffusion and somewhat more mixed and heterogeneous evidence supporting the role of exports. The literature recognized that simply providing for trade is not enough for a country to benefit from foreign technology. Other conditions related to absorptive capacities need to be satisfied for technological diffusion to be successful in the sense of productive implementation of technology in the production process. Analysis of international technology transfer has incorporated absorptive capactities mainly through the analysis of technological spillovers, but 
the main focus of this literature is on channels of international technology transfer. Therefore, next to to the overview of economic literature analysing international channels of technology transfer we also provide discussion on the role of absorptive capacities in the process of technology transfer.

\subsection{International trade as the channel of technology transfer}

International trade serves as the major channel of technology transfer, primarily because imported intermediate goods can contain a significant technological component (Broadberry 1992). Coe et al. (1997) point to several other channels through which imports serve as a way to transfer technology internationally. Namely, imported intermediate goods raise domestic productivity; learning about better production methods, product design or organizational structures might result in more efficient domestic production; imitation of new products and new technology can significantly increase domestic technological capacity, adjustment and improvement of new products can improve quality of goods produced domestically. Furthermore, interactions with foreign companies provide information about new products and practices (Greenaway and Kneller 2007) as well as the technical assistance (Pack and Saggi 2001) to local firms that allow them to produce at lower cost and higher quality. This effect might be of a higher importance for developing countries. Finally, higher competition in the international market might serve as an incentive to increase efficiency (Greenaway and Kneller 2007). Exports also play an important role in the international technological diffusion since they contain information from international buyers about frontier design specifications and production techniques, as well as securing a competitive environment.

The literature on the role of trade in the international technological diffusion has focused on both firm (industry) and aggregate level analysis. Aggregate level studies suggest that domestic and foreign knowledge stocks influence domestic productivity. Coe and Helpman (1995) analyze the importance of imports in facilitating R\&D spillovers in the sample of OECD countries. First they create a measure of the stock of foreign knowledge and then they regress TFP on the foreign and domestic stock of knowledge. The results point that both stocks of knowledge are important for productivity increases but the foreign stock is more important for bigger countries. Coe et al. (2009b) use somewhat different approach to calculate the stocks of knowledge and find only weak evidence for foreign knowledge spillovers. Authors suggest that using bilateral import weights or simple averages produces better results than random weights when constructing the stock of knowledge. Different approaches to calculating the stocks of knowledge and trade weightings have also been suggested in the literature, for example Xu and Wang (1999) use capital goods imports as weights instead total imports and Funk (2001) and Falvey et al. (2004) use exports rather than imports. Kao et al. (1999) also criticize the results of Coe and Helpman (1995), especially due to the small estimated coefficients and low statistical significance, and use non-stationary panel approach to examine the significance of foreign knowledge spillovers. The results confirm positive spillover effects but the coefficient of interest is still not significant. Coe et al. (2009b) investigate spillovers from North to South and confirm that spillovers are an important source of productivity growth, where imports play the most important role. The importance of spillovers has been confirmed (Keller 2000), although by using more disaggregated sample.

Significant number of papers investigated the role of trade for technological transfer on the disaggregated, industry or firm level. The main focus of these papers has been to analyze why some firms export while others focus on the domestic market exclusively and to investigate the relationship between exporting and productivity. Girma et al. (2004) conclude that in the presence of the market research costs, product modification costs, compliance and other sunk costs, the firms will engage in international markets only if the present value of their profits exceeds the costs of foreign market entry. The consensus in the literature about the relationship between exporting and firm productivity is that best firms self-select into exporting (Fryges and Wagner 2007; Isgut 2001) as well as that there are strong effects of learning through exporting (Aw et al. 2000; Renard 2002) as they create information flows with international buyers, allow access to better institutional framework and incentives to raise productivity. The other strand of literature pointed to the productivity gains that come from an increased competitive pressures in the international market which forces firms to increase their productive capacity. However, most studies conclude in favor of self-selection argument rather than learning by exporting. It is important to point that this conclusion is very dependent on the sample used. For example, the evidence of learning effects tends to be much stronger in developing countries. The issue of causality has been an important empirical difficulty in this line of research, namely, if firms, or treated units, are not drawn from the random sample but are rather 
selected or self-selected according to some a-priori criteria, the effect of the treatment cannot be statistically taken into account and results will be biased. Girma et al. (2003) and Girma et al. (2004) propose the matching approach as a remedy which has proven to be a very promising research line.

Fryges and Wagner (2007) suggest that the export intensity might play an important role in boosting the firm's productivity mainly due to the intensity of contacts with foreign customers where authors claim that more contact implies more intensive spillovers. Authors also point to the potential of incurring increased costs of exporting in terms of organization, coordination and control costs. Some authors (Damijan et al. 2004) pointed to the importance of destination in the process of exporting, for example, De Loecker (2007) finds evidence that Slovenian firms incur gains in productivity only when they export to the more advanced country. Although most of the focus of the empirical firm-level literature was on the connection between exports and firm productivity, the imports might also bring significant benefits to productivity growth. Imported capital and intermediate goods can bring in new knowledge and technology that can improve countries productivity through intermediates of better than domestic quality, using complementary intermediates where different combinations of intermediates creates gains that are more than just a sum of its parts. Halpern et al. (2011) use data on Hungarian firms to investigate the effect of imported inputs on productivity and their results confirm that imports can bring significant positive effects for productivity and that there are many complementarity effects in that process. On the other hand, Keller and Yeaple (2009) don't find much evidence supporting the view that spillovers related to imports are important in the sample of US firms.

\subsection{Foreign direct investments}

Apart from trade, the FDI is the second major channel of technology transfer and has received a lot of attention in the literature. The FDI usually implies a direct transfer of technology from the parent firm abroad but the technology within the FDI process can also spill over to the domestic firm from a foreign competitor, customer or supplier, for example, through learning about new business practices and products or through the employment of workers that have foreign experience. However, there is some indication that FDI might be a suboptimal channel for technological diffusion mainly due to the fact that FDI keeps the technology within the firm so the technology might be difficult to diffuse in the local economy.

FDI can be vertical, where the subsidiary produces output that is used as an input of another subsidiary or even the parent company itself, or horizontal, in which the subsidiary produces the product similar to the parent firm. FDI is usually a characteristic of technologically more advanced industries where knowledge and technology play an important role. The motivation for FDI is therefore related to the ease of transferring knowledge and technology internationally due to possibility of using the same technology on many different locations without any loss of its characteristics. The literature suggests that FDI is dependent on the location, market size, availability of skilled workforce, availability of resources and distance from markets of interest as well as production costs.There are many channels within FDI through which technology diffuses. For example, productivity spillovers can result from FDI but also from the impact of FDI on the market structure (Blomstrom and Kokko 1998) so the evidence from both horizontal and vertical spillovers can be vague. Important channel of technology diffusion through FDI are also backward linkages of domestic firms with local suppliers (Pack and Saggi 2001).

Some authors focused on the aggregate level data to examine the effect of FDI on productivity. The evidence using that data is quite mixed. The effect is confirmed in Borensztein et al. (1998) that finds evidence about positive impact of FDI on growth in countries with sufficient human capital. Blomstrom and Kokko (1994) and Alfaro et al. (2004) confirm that result but add that effects are stronger in rich countries. On the other side, Xu (2000) find little evidence that inward FDI brings important technological benefits but some evidence suggesting that outward FDI might have a bigger role. This result is confirmed in Globerman et al. (2000) that use different type of data set, mainly focusing on patent citation data. Next to aggregate level studies, there is a significant literature that focused on industry and firm level data when analyzing the relationship between FDI and economic performance. The research has focused on investigating whether domestic firms benefit from the presence of foreign firms in their industry or geographical location. Due to significant differences between foreign and domestic firms, especially in terms of specific knowledge about production, management and marketing techniques, export contacts and specific relationship with buyers and suppliers, the researchers have analyzed if these differences make for a better business performance of foreign firms relative to their domestic counterparts but also if there are spillovers from foreign firms to domestic firms, industries or country. The first research line is related to the analysis of specific advantages of 
foreign owned firms that make them have a comparative advantage relative to domestic ones.

It is important to note that FDI might also reduce the productivity of domestic firms, for example, because of increased competition (Harris 2009). The negative effects for both foreign and domestic firms might be stronger in the beginning phase of the business and are expected to last only for short term. These negative effects might be related to the process of acquiring a specific knowledge about the business in the local country which can reduce the business efficiency or decision of a foreign company to keep their value-added operations in their home market, keeping the lower value operations in the host country (Javorcik 2004). All this can lead to lower productivity of local plants.

The analysis of relative performance between foreign and domestic companies has also been in the focus of number of papers. Griffith et al. (2004) uses the sample of UK companies to show that foreign companies do not outperform domestic ones. Harris (2002) criticizes these findings on the basis of a sample selection bias and confirms that foreign owned companies are significantly more productive. Harris and Robinson (2003) methodologically extend the Harris (2002) approach to confirm that the foreign owned companies (from US) perform better than domestic ones. The evidence for the global sample shows that foreign firms do not necessarily outperform. These results are also confirmed for transition economies (Yasar and Morrison Paul 2007). Interestingly, the analysis of exporting firms shows that exporters perform better in terms of productivity and that foreign owned exporting firms perform better than domestically owned exporters.

Spillovers from FDI have also been recognized as an important way the technology diffuses in the country. The difficulty with diffusion of FDI spillovers is related to the reluctance of foreign firms to pass over the advanced technology to competing local firms, exactly because this technology makes for their competitive edge relative to local firms. However, not all technology is possible to keep within the firm and diffusion takes place through imitation, acquiring of new skills, increased competition and others. Imitation seems to be a very important way for the technology to spill over from FDI into the industry and the rest of the economy. It is important to note that imitation includes not only product imitation but also the imitation of organizational and managerial processes, reverse engineering or simply the employment of skilled workforce from abroad.

Falvey et al. (2004) stresses the new skills acquisition as an important way the spillovers occur and
Blomstrom and Kokko (1998) point to the role of foreign companies in bringing the new products which can serve as a signal for local companies to engage in developing similar products. Bernard et al. (2007) stress the importance of information exchange between foreign and local companies for later to start the exporting activity. Namely, foreign owned companies are expected to have a know-how about more efficient production methods and export markets which can reduce costs of engaging in exporting for local firms. However, the absorption of new technology and efficiency of spillovers absorption might be crucially related to the technological gap where countries (companies) that are characterized by a bigger technological gap could have difficulties in applying the frontier technology in their local economies (Findlay 1978).

Significant positive effects of FDI spillovers are confirmed in large number of studies (Grg and Greenaway 2004). This result might be conditional on the sample choice as well as methodology used. Some studies confirmed the positive effect of spillovers only in the sample of developed countries (Haskel et al. 2007; Keller and Yeaple 2009). However, it is important to note that many of the studies that find positive effects are based on cross-sectional data which suffer from the aggregation problem and as such do not take into account time invariant differences of productivity across different sectors of economy. The results might therefore be biased. Panel studies allow for fixed effects and produce significantly less evidence in favor of positive FDI spillovers which might be an another evidence that many of the results in the literature are methodologically dependent. The size of the sample, the level of aggregation and the data span of the analysis might have also influenced the consensus about the importance of spillovers. This is confirmed in the meta study of Havranek and Irsova (2010) and Wooster and Diebel (2010)) that review significant number of different studies.

\subsection{Absorption capacities (R\&D, Human capital and Investments)}

Early attempts to proxy for absorption capacities used distance with respect to the technology frontier (Nelson and Phelps 1966) as a measure of how fast the country's technological gap reduces. Newer literature points to the importance of local conditions, especially for spillovers to be effective, and for new technology to get productively implemented. Local conditions are most widely proxied by human capital, whose importance was stressed out in the endogenous growth 
framework. In these models, production function is extended to include variety of measures of human capital, which than determines how much and what kind of foreign technology will difuse in the local economy. Absorption capacities are found to have importance in development gap reduction between countries, especially when proxied by human capital and for the sample of developing countries (Behabib and Spiegel 1994). Human capital is confirmed to influence technological gap reduction for 53 countries between 1970 and 1990 (Mayer 2001) and 84 countries between 1960. and 1995. (Behabib and Spiegel 2002). Comin and Hobijin (2004) analyse long historical period for the sample of developed and developing economies and conclude that technological diffusion determines how much of international technological transfer becomes sucessful, whereby human capital, trade regime and overall technology level play the main role. Other authors (Falvey at al. 2002) pointed out that overall technology level of a country may exhibit treshold relationship with the reduction of technology gap, where certain level of development is necessary for a country to be able to benefit from advanced technology. Debate that developed around this issue mainly agrees that most advanced technologioes might have difficulties beeing transfered internationaly but countries behind the technological frontier will benefit from them, however, only in case a country is not too far behind.

Absorptive capacities are found to have influence on spillover effects, which play the main role in the process of technology transfer. Crespo Cuaresma et al. (2004) confirm that spillover effects are stronger in countries that invest more in R\&D and have more human capital within the domestic economy whereas Coe et al. (2009a) point to the importance of the institutional framework and legal protection for the $R \& D$ spillovers. Some authors used the patent data as a technological proxy because it identifies well the general technological capacity. For example, Sjholm (1996) uses patent data to conclude that there is a positive correlation between patent data and imports which points to the importance of trade for technological spillovers. Other widely used measures for absorptive capacities include R\&D intensity, human capital and for developing countries, quality of institutions and formation of fixed capital might be of importance. Absorptive capacities determine not only speed of the technology transfer but also the level of technology one coutntry is able to process.

There is variety of other ways in which absorptive capacities affect growth. Some of them have sectoral effects, where Keller and Yaple (2009) point that FDI might have different effects in different sectors of economy, mostly due to varying technological gap between sectoral leaders (i.e. FDI firms) and incumbent firms. The strongest FDI effect is found in sectors with biggest differences so authors conclude that absorptive capacities might play different role in the process of technological transfer on the sectoral than agregate level. Girma and Gorg (2007) add to that evidence by showing that investment effectivnes of FDI varies between industries and variance is explained by differences in firm's competitivness as a measure of absorptive capacity. Parente and Presocott (2004) point to institutional barriers for technology transfer as costs that firms idirectly incur, which is later on reflected in their wilingness to invest in new technologies. Local labour maket can also be a big inibiting factor to absorption of advanced technology, for example because unequal distribution of skilled wokers across sectors might attract unequal technological investment (Acemoglu and Zilibotti 1999), causing distruptions in overall economic growth. Other authors point to range of obstacles on the agregate level for technolgy absorption like low educational levels, obstacles to trade, low quality legal framework and institutions (Isaksson 2001).

\section{DATA AND METHODOLOGY}

In our analysis we dominantly use Eurostat database (Gonalves 2015) and Penn World Table 8.1 database (Feenstra et al. 2015). The series on TFP and Human capital are collected from PWT 8.1 database and refer to the variable RTFP that is calculated so to obtain productivity growth rates for each country in a way that is convenient for cross-country comparisons over time and $\mathrm{HC}$ variable that is an estimate of human capital based on average years of schooling and returns to schooling. The data is obtained on a yearly frequency spanning the period from 1950 until 2014.

When it comes to Eurostat, direct investment in the reporting economy, both flows and stocks (tipsbp90, tipsbp100) expressed as \% of GDP are used in the analysis as a proxy for FDI channel of diffusion. Gross domestic expenditure on research and development (R\&D) expressed as \% of GDP (tipsst10) is used as an proxy for R\&D activity in the member state. Gross fixed capital formation (investments as \% GDP) is used as a proxy for real investments (tec00011) and exports and imports of goods and services (nama_10_gdp, P6 and P7) are used as an proxy for openness. All Eurostat data has been download using Gonalves (2015) approach.

Entire time span is used for log t test, while in the PVAR model only data after 1995 are employed due to lack of data availability for other variables prior to 
1995. We have decided to use all variables expressed in terms of the GDP share in order to control for the relative size of EU economies.

We employ Abrigo and Love (2016) PVAR methodology in order to estimate the Granger causality and impulse response functions between TFP and vector of variables that proxy for channels of technological transfer. Test is employed on entire sample as well as on two clubs of coutries that were grouped in two separate convergance clubs using Phillips and Sul (2007) $\log t$ test. All tests are done in the panel data setting which allows for coherent identification of variable relationships in tested groups of countres.

\subsection{Log t test}

In the first step we employ Phillips and Sul (2007) log t test in order to identify endogenous TFP convergence clubs within our sample of countries. One of the key advantages of this method is the fact that log t test can detect convergence even in the case of transitional divergence, where other methods such as stationarity or convergence tests fail (Phillips and Sul 2007, p.1778). ${ }^{1}$

Log t test tests for covergance of TFP (in this case) between all countries in the sample and if convergence is rejected with log t test, estimation proceedes by grid search of various combination of countries until statistical indicators of the log $t$ test are maximised. In the end countries are grouped in one or more clubs that according to log $t$ test show signs of convergence.

In order to develop statistical indicators that are used to endogenously group countries in clubs, Phillips and Sul (2007) start from the basic premise that panel data decomposition where $q_{i t}$ embodies systematic component (cross-section dependence) and $a_{i t}$ that represents transitory component.

$X_{i t}=g_{i t}+a_{i t}$

Furthermore, they transform equation 1 in order to separate common $\mu_{t}$ from idiosyncratic component $\delta_{t}$ in the panel,

$X_{i t}=\frac{q_{i t}+a_{i t}}{\mu_{t}}=\delta_{i t} \mu_{t}$

Thus, $\delta_{i t}$ represents individual economic distance between common trend component $\mu_{t}$ and $X_{i t}$. In order to avoid problems with estimation of $\delta$, a common

1 The results of standard convetional stationarity and cointegration tests are avilable per request. factor $\mu$ is removed from equation 2 by scaling

$h_{i t}=\frac{X_{i t}}{\frac{1}{N} \sum_{t=1}^{N} X_{i t}}=\frac{\delta_{i t}}{\frac{1}{N} \sum_{t=1}^{N} \delta_{i t}}$

which measures loading coefficient $\delta_{i t}$ in relation to panel average at time $t$ (under assumption that panel average differ from zero). $h_{i t}$ represents transition path of economy and measures the individual behavior in relation to other economies (common growth path). In the case of convergence, parameter $h_{i t}$ converge to unity and it's cross sectional variance converges to zero.

To test for the convergence, Phillips and Sul (2007) suggest to use cross section variance ratio $H_{1} / H_{t}$ in order to estimate following regression:

$$
\begin{aligned}
& \log \left(H_{1} / H_{t}\right)-2 \log \mathrm{L}(t)=\hat{\alpha}+\hat{b} \log t+\hat{u}_{t} \\
& \mathrm{t}=\mathrm{rT}, \mathrm{rT}+1, \ldots, \mathrm{T}
\end{aligned}
$$

$r$ is between zero and 1 and the fitted coefficient of $\log \mathrm{t}$ is $\hat{b}=2 \hat{a}$, where $\hat{a}$ is estimate of $\alpha$ in the null hypothesis.

Phillips and Sul (2007) suggest using $L(t)=\log t$ and $r=0.3$ for small samples beneath $T=50$. The null hypothesis of convergence imply that $\delta_{i}=\delta$ and $\alpha \geq 0$, while alternative hypothesis implies that $\delta_{i} \neq \delta$ a n d $\alpha<0$. The null hypothesis is rejected if $t b<-1.65$ at $5 \%$ significance level.

If the convergence for the entire group of countries is rejected, tests of convergence are conducted for the subsamples of countries. First, subgroup of countries $G_{k}$ consisting of $k$ countries is formed using last observation ordering. In the second step convergence test statistics is calculated $t_{k}=t\left(G_{k}\right)$ for the subgroup. Group size is chosen by maximizing $t_{k}$ over $k$ under the condition $\min \left(t_{k}\right)>-1.65$ in order to ensure that subgroup is converging.

Steps are repeated until all convergence clubs have been identified. In the final test, convergence between subgroups is also tested. The countries that do not belong to subgroups are considered to be diverging countries.

\subsection{PVAR model}

After the convergence test, we use panel VAR model in order to identify channels of technological diffusion. A reduced form panel VAR model is employed to examine the dynamic effects between TFP and diffusion channels such as openness, investment, R\&D, FDI, etc. 


$$
\begin{aligned}
& \text { TFP } P_{i, t}=\alpha_{1 i}+\gamma_{1 t}+\rho_{11} T E P_{i, t-1}+. . \\
& +\rho_{1 k} T F P_{i, t-k}+\beta_{11} X_{i, t-1}+. . \\
& +\beta_{1 k} X_{i, t-k}+e_{1 i t} \\
& X_{i, t}=\alpha_{2 i}+\gamma_{2 t}+\rho_{21} X_{i, t-1}+. . \\
& +\rho_{2 k} X_{i, t-k}+\beta_{21} T E P_{i, t-1}+. . \\
& +\beta_{2 k} T F P_{i, t-k}+e_{2 i t} .
\end{aligned}
$$

Unlike the usual time series VAR model, one complication of estimating these panel VAR models lies in how to deal with the terms for unobserved heterogeneity, $a_{1 i}$ and $a_{2 i}$. We employ the GMM estimation procedure of Holtz-Eakin et al. (1988) for estimating following procedure by Abrigo and Love (2016) in order to minimize loss of data points used within the estimation.

\section{RESULTS}

Tables 1 presents log $t$ test results for $28 \mathrm{EU}$ member states in the second column. Estimated coefficient is negative and $t$ statistics is below critical value implying the rejection of null hypothesis. Due to rejection of convergence for the 28 member countries, log t test is employed in order to investigate for the existance of convergence in a subset of countries. Third and fourth column of the Table 1 present results of the log t test for the two endogenously estimated convergence clubs. Members of two estimated subsets of countries are presented in Table 2.

According to log $t$ test procedure, in the first convergence club there are 16 countries, mostly EU-15 old members with exception of Malta, Hungary and Poland. In the second club, members are mostly new EU members while Portugal and Greece are part of the convergence club although they are old EU members. These results are along the lines of literature on convergence clubs in EU where good amount of empirical evidene points to old member states forming one, and new members another convergence club. Convergence clubs can vary when countries are added or taken away from the testing sample but two clubs have robustly been identified fo the sample of EU countries. Our results confirm these findings and also point that heterogenity of clubs might be more pronounced for peripheral EU countries, while at the same time dependant on methodological approach used. Therefore we see results of our convergence tests as a confirmation of multiple convergence clubs within the group of EU countries where length of EU membership plays importance in explaining
Table 1: Covergence Test

\begin{tabular}{cccc}
\hline \multicolumn{4}{c}{ TFP convergence test } \\
\hline $\log (\mathrm{t})$ & All Coutries & Club1 & Club2 \\
Coeff & -0.664 & 0.391 & 0.393 \\
t-stat & -14.52 & 25.52 & 5.365 \\
\hline
\end{tabular}

Table 2: Members of the Convergence Clubs

$$
\text { Club 1: (16) }
$$

| Austria | Belgium | Denmark | Finland | France | Germany | | Hungary | Ireland | Italy | Luxembourg | Malta | Netherlands| | Poland | Spain | Sweden | United Kingdom |

Club 2: (12)

| Bulgaria | Croatia | Cyprus | Czech Republic | Estonia | Greece| | Latvia | Lithuania | Portugal | Romania | Slovakia | Slovenia |

Table 3: Convergence Club Merging

\begin{tabular}{cc}
\hline \multicolumn{2}{c}{ TFP convergence test } \\
\hline $\log (\mathrm{t})$ & Club1+2 \\
Coeff & -0.664 \\
T-stat & -14.52 \\
\hline
\end{tabular}

formation of these clusters. Estimated statistics for both clubs ( $3 r d$ and 4 th column in Table 1) imply that null hypothesis of convergence can not be rejected. Coefficients are positive and t statistics is higher than critical values.

We run several robustness tests to control for possible variability in our endogenous clustering procedure, mainly by adding and subtracting different countries to the empirical sample. Firstly, in Table 3 we present results of the test of convergence between means of the endogenously estimated convergence clubs presented in Table 2 . Results are positive and indicate rejection of null hypothesis between two clubs of countries. Table 4 presents the members of endogenously estimated convergence clubs if four non-EU countries are added to our sample as a robustness test. Addition of Norway, Switzerland, Iceland and Russia to our sample, results in the third convergence club. A new club had Cyprus, Lithuania and Norway as members, Iceland and Russia converge to new Europe club and Switzerland to the EU old members. Addition of three more non-EU countries (Serbia, Moldova and Ukraine) breaks new Europe convergence club into 
Table 4: Members of the Convergence Clubs - EU plus Norway, Switzerland, Iceland and Russia

$$
\text { Club 1: (17) }
$$

| Austria | Belgium | Denmark | Finland | France | Germany | | Hungary | Ireland | Italy | Luxembourg | Malta | Netherlands |

| Poland | Spain | Sweden | Switzerland | United Kingdom |

Club 2: (3)

| Cyprus | Lithuania | Norway |

Club 3: (12)

| Bulgaria | Croatia | Czech Republic | Estonia | Greece | Iceland | | Latvia | Portugal | Romania | Russia | Slovakia | Slovenia |

Table 5: Members of the Convergence Clubs - all Eurostat countries

Club 1: (17)

| Austria | Belgium | Denmark | Finland | France | Germany | | Hungary | Ireland | Italy | Luxembourg | Malta | Netherlands |

| Poland | Spain | Sweden | Switzerland | United Kingdom |

Club 2: (3)

| Cyprus | Lithuania | Norway |

Club $3:(5)$

| Iceland | Portugal | Romania | Russia | Slovakia |

Club 4: (10)

| Bulgaria | Croatia | Czech Republic | Estonia | Greece | Latvia | Moldova | Serbia | Slovenia | Ukraine |

two convergence groups. A new convergence club has Iceland, Portugal, Romania, Russia and Slovakia (Table 5).

After convergence tests, we investigate the process of technology transfer in previously identified groups of countries. Granger causality test is used on cointegrated groups to analyze significance of main technological transfer channels as well as different absorptive capacitites. Table 6 presents results for the estimated PVAR model together with Granger causality test results for all EU member states. Natural log of deviation of TFP from cross-section mean is the first dependent variable in all six models where Human capital, Exports, FDI flow, GFCF, Imports, FDI stock, and $R \& D$ are rotated as second dependent variable in models 1 through 7. Lag length of one is used to estimate equation 5 using the Abrigo and Love (2016)
PVAR procedure.

In the second to last row of Table $6 p$-values for the Granger causality test between TFP and variables that proxy channels and absorption capacities (Imports, Exports, FDI flow, FDI stock, Human capital, GFCF, and R\&D) of diffusion are presented. The null hypothesis is rejected for FDI stocks and R\&D expenditure. Furthermore, statistical sign for the estimated coefficient is positive and significant at $1 \%$.

The last row of Table 6 shows p-values of the Granger causality test for the reverse direction of causality going from TFP to channels of diffusion. The null hypothesis is rejected for Exports, GFCF, Imports as well as FDI stocks.

Having in mind the results for endogenous clubs of EU countries, the estimation is repeated using data for the 16 countries from the club 1 (Core EU members) from the Table 2. Table 7 presents results of the PVAR model and Granger Causality test for the Core group of countries. ${ }^{2}$ P-values for the null hypothesis that proxies for the channels of diffusion of technology do not Granger cause TFP are presented in the second to last row of the Table 7. The null hypothesis is rejected at conventional levels of significance for the Exports, FDI flows, Imports and FDI stocks. Estimated coefficients in the PVAR model are significant for all four variables, but the estimated sign is opposite to the theoretically expected sign in all cases. Obviously, although these variables Granger cause TFP, their growth does not affect TFP in the positive way. Old EU members seem not to significantly depend on technological transfer for their economic growth, which is resonable taken that they have significant stocks of technology and already are generating new technologies within their economy. Having in mind that TFP is expressed as a log difference from the cross-section mean, our results might imply that most of the TFP is not diffused in classical way within this group of countries. Furthermore, trade and FDI from other countries of the world might play an important role, for example bilateral trade or inestments from USA as a technological frontier, would be expected to have stronger (positive) effects on technology transfer,

When it comes to Periphery countries (Club 2 from Table 2), Table 8 presents results of PVAR model and Granger causality test. Again, p-values for the null that diffusion variables do not Granger cause TFP are shown in the second to last row of the table. The null hypothesis is rejected at standard confidence levels for Human capital, Imports and R\&D expenditures. On the other hand, estimated coefficients are positive

2 Club 1 includes mostly EU-15 old members with addition of Malta, Hungary and Poland and without Portugal and Greece. 
Table 6: PVAR model and Granger Causality Test - all EU members

\begin{tabular}{|c|c|c|c|c|c|c|c|}
\hline Models: & (1) & $(2)$ & (3) & (4) & (5) & (6) & (7) \\
\hline & Human cap. & Export & FDI flow & Investment & Import & FDI stock & $R \& D$ \\
\hline \multicolumn{8}{|c|}{$T F P_{i t}$} \\
\hline \multirow[t]{2}{*}{ Lag of TFP } & $0.870 * * *$ & $1.017^{* * *}$ & $1.010^{* * *}$ & $1.007^{* * *}$ & $1.031^{* * *}$ & $1.019^{* * *}$ & $1.028^{* * *}$ \\
\hline & $(15.29)$ & $(67.21)$ & (312.74) & (397.27) & $(77.21)$ & $(194.68)$ & $(100.88)$ \\
\hline \multirow[t]{2}{*}{ Lag of Human capital } & 0.168 & & & & & & \\
\hline & $(0.79)$ & & & & & & \\
\hline \multirow[t]{2}{*}{ Lag of exports } & & 0.002 & & & & & \\
\hline & & $(0.96)$ & & & & & \\
\hline \multirow[t]{2}{*}{ Lag of flows of FDI } & & & -0.000 & & & & \\
\hline & & & $(-0.08)$ & & & & \\
\hline \multirow[t]{2}{*}{ Lag of Investments } & & & & -0.002 & & & \\
\hline & & & & $(-0.99)$ & & & \\
\hline \multirow[t]{2}{*}{ Lag of Imports } & & & & & -0.005 & & \\
\hline & & & & & $(-0.75)$ & & \\
\hline \multirow[t]{2}{*}{ Lag of stock of FDI } & & & & & & $0.005^{* * *}$ & \\
\hline & & & & & & $(3.19)$ & \\
\hline \multirow[t]{2}{*}{ Lag of R\&D } & & & & & & & $0.019^{* * *}$ \\
\hline & & & & & & & $(4.00)$ \\
\hline \multicolumn{8}{|c|}{$X_{i t}=$ Human capital } \\
\hline \multirow[t]{2}{*}{ Lag of TFP } & 0.000 & & & & & & \\
\hline & $(0.07)$ & & & & & & \\
\hline \multirow[t]{2}{*}{ Lag of Human capital } & $0.895^{* * *}$ & & & & & & \\
\hline & $(24.67)$ & & & & & & \\
\hline \multicolumn{8}{|c|}{$X_{i t}=$ Export } \\
\hline \multirow[t]{2}{*}{ Lag of TFP } & & $0.322^{* * *}$ & & & & & \\
\hline & & $(4.39)$ & & & & & \\
\hline \multirow[t]{2}{*}{ Lag of exports } & & $0.304^{*}$ & & & & & \\
\hline & & $(1.73)$ & & & & & \\
\hline \multicolumn{8}{|c|}{$X_{i t}=$ FDI flow } \\
\hline Lag of TFP & & & 26.486 & & & & \\
\hline & & & $(1.36)$ & & & & \\
\hline Lag of flows of FDI & & & $0.662^{* * *}$ & & & & \\
\hline & & & $(9.41)$ & & & & \\
\hline & & & it $=$ Investn & & & & \\
\hline Lag of TFP & & & & $-0.009^{* *}$ & & & \\
\hline & & & & $(-2.19)$ & & & \\
\hline Lag of Investments & & & & $0.995^{* * *}$ & & & \\
\hline & & & & $(590.46)$ & & & \\
\hline & & & $X_{i t}=\operatorname{Impc}$ & & & & \\
\hline Lag of TFP & & & & & $0.143^{* *}$ & & \\
\hline & & & & & $(2.56)$ & & \\
\hline Lag of Imports & & & & & -0.028 & & \\
\hline & & & & & $(-0.27)$ & & \\
\hline & & & $X_{i t}=$ FDI st & & & & \\
\hline Lag of TFP & & & & & & $-0.613^{* *}$ & \\
\hline & & & & & & $(-2.41)$ & \\
\hline Lag of stock of FDI & & & & & & $0.334^{* * *}$ & \\
\hline & & & & & & $(3.68)$ & \\
\hline & & & $X_{i t}=\mathrm{R} \&[$ & & & & \\
\hline Lag of TFP & & & & & & & 0.070 \\
\hline & & & & & & & $(0.70)$ \\
\hline Lag of R\&D & & & & & & & $0.764^{* * *}$ \\
\hline & & & & & & & $(9.37)$ \\
\hline $\mathrm{N}$ & 1325 & 565 & 347 & 196 & 565 & 325 & 479 \\
\hline & & p-values & the Grang & ausality test & & & \\
\hline$X_{i, t}$ to $T F P_{i, t}$ & 0.427 & 0.336 & 0.933 & 0.323 & 0.456 & $0.001^{* * *}$ & $0.000^{* * *}$ \\
\hline$T F P_{i, t}$ to $X_{i, t}$ & 0.946 & $0.000^{* * *}$ & 0.174 & $0.028^{* *}$ & $0.010^{* * *}$ & $0.016^{* *}$ & 0.486 \\
\hline
\end{tabular}

Note: $t$ statistics in parentheses, ${ }^{*},{ }^{* *},{ }^{* *}$ denotes statistical significance at 10,5 , and $1 \%$ respectively. 
Table 7: PVAR model and Granger Causality Test - Core (Club 1)

\begin{tabular}{|c|c|c|c|c|c|c|c|}
\hline Models: & (1) & (2) & (3) & (4) & (5) & (6) & (7) \\
\hline & Human cap. & Export & FDI flow & Investment & Import & FDI stock & $R \& D$ \\
\hline \multicolumn{8}{|c|}{$T F P_{i t}$} \\
\hline \multirow[t]{2}{*}{ Lag of TFP } & $0.956^{* * *}$ & $1.047^{* * *}$ & $0.999 * * *$ & $1.014^{* * *}$ & $1.043^{* * *}$ & $1.017^{* * *}$ & $1.027^{* * *}$ \\
\hline & $(17.94)$ & (91.49) & $(213.26)$ & $(183.83)$ & (89.48) & $(211.12)$ & $(136.65)$ \\
\hline \multirow[t]{2}{*}{ Lag of Human capital } & -0.002 & & & & & & \\
\hline & $(-0.01)$ & & & & & & \\
\hline \multirow[t]{2}{*}{ Lag of exports } & & $-0.012^{* * *}$ & & & & & \\
\hline & & $(-5.24)$ & & & & & \\
\hline \multirow[t]{2}{*}{ Lag of flows of FDI } & & & $-0.000^{* *}$ & & & & \\
\hline & & & $(-2.02)$ & & & & \\
\hline \multirow[t]{2}{*}{ Lag of Investments } & & & & -0.002 & & & \\
\hline & & & & $(-0.40)$ & & & \\
\hline \multirow[t]{2}{*}{ Lag of Imports } & & & & & $-0.012^{* * *}$ & & \\
\hline & & & & & $(-4.19)$ & & \\
\hline \multirow[t]{2}{*}{ Lag of stock of FDI } & & & & & & $-0.001^{* * *}$ & \\
\hline & & & & & & $(-2.76)$ & \\
\hline \multirow[t]{2}{*}{ Lag of R\&D } & & & & & & & 0.001 \\
\hline & & & & & & & $(0.51)$ \\
\hline \multicolumn{8}{|c|}{$X_{i t}=$ Human capital } \\
\hline \multirow[t]{2}{*}{ Lag of TFP } & -0.000 & & & & & & \\
\hline & $(-0.08)$ & & & & & & \\
\hline \multirow[t]{2}{*}{ Lag of Human capital } & $0.973^{* * *}$ & & & & & & \\
\hline & $(38.63)$ & & & & & & \\
\hline \multicolumn{8}{|c|}{$X_{i t}=$ Export } \\
\hline \multirow[t]{2}{*}{ Lag of TFP } & & 0.033 & & & & & \\
\hline & & $(0.57)$ & & & & & \\
\hline \multirow[t]{2}{*}{ Lag of exports } & & $0.621 * * *$ & & & & & \\
\hline & & $(4.35)$ & & & & & \\
\hline \multicolumn{8}{|c|}{$X_{i t}=$ FDI flow } \\
\hline Lag of TFP & & & 63.112 & & & & \\
\hline & & & $(1.44)$ & & & & \\
\hline Lag of flows of FDI & & & $0.348^{* * *}$ & & & & \\
\hline & & & (3.97) & & & & \\
\hline & & & $X_{i t}=$ Invest & & & & \\
\hline Lag of TFP & & & & $-0.053^{* * *}$ & & & \\
\hline & & & & $(-4.08)$ & & & \\
\hline Lag of Investments & & & & $0.950^{* * *}$ & & & \\
\hline & & & & $(67.42)$ & & & \\
\hline & & & $X_{i t}=\mathrm{Imp}$ & & & & \\
\hline Lag of TFP & & & & & -0.027 & & \\
\hline & & & & & $(-0.48)$ & & \\
\hline Lag of Imports & & & & & $0.413^{* * *}$ & & \\
\hline & & & & & $(3.11)$ & & \\
\hline & & & $X_{i t}=\mathrm{FDI} \mathrm{s}$ & & & & \\
\hline Lag of TFP & & & & & & $-1.774^{* * *}$ & \\
\hline & & & & & & $(-6.16)$ & \\
\hline Lag of stock of FDI & & & & & & $0.339^{* * *}$ & \\
\hline & & & & & & $(7.04)$ & \\
\hline & & & $X_{i t}=\mathrm{R} \&$ & & & & \\
\hline Lag of TFP & & & & & & & 0.069 \\
\hline & & & & & & & $(0.42)$ \\
\hline Lag of R\&D & & & & & & & $0.853^{* * *}$ \\
\hline & & & & & & & $(7.82)$ \\
\hline $\mathrm{N}$ & 916 & 349 & 205 & 112 & 349 & 193 & 276 \\
\hline & & $\mathrm{p}$-value & the Grang & causality test & & & \\
\hline$X_{i, t}$ to $T F P_{i, t}$ & 0.992 & $0.000^{* * *}$ & $0.043^{* *}$ & 0.689 & $0.000 * * *$ & $0.006^{* * *}$ & 0.613 \\
\hline$T F P_{i, t}$ to $X_{i, t}$ & 0.937 & 0.568 & 0.149 & $0.000^{* * *}$ & 0.628 & $0.000^{* * *}$ & 0.678 \\
\hline
\end{tabular}

Note: $t$ statistics in parentheses, ${ }^{*},{ }^{* *},{ }^{* *}$ denotes statistical significance at 10,5 , and $1 \%$ respectively. 
Table 8: PVAR model and Granger Causality Test - Periphery (Club 2)

\begin{tabular}{|c|c|c|c|c|c|c|c|}
\hline Models: & (1) & (2) & (3) & (4) & (5) & (6) & (7) \\
\hline & Human cap. & Export & FDI flow & Investment & Import & FDI stock & $R \& D$ \\
\hline \multicolumn{8}{|c|}{$T F P_{i t}$} \\
\hline \multirow[t]{2}{*}{ Lag of TFP } & $0.953^{* * *}$ & $1.052^{* * *}$ & $0.996^{* * *}$ & $1.008^{* * *}$ & $1.040^{* * *}$ & $1.038^{* * *}$ & $1.023^{* * *}$ \\
\hline & $(14.17)$ & $(113.63)$ & $(81.87)$ & $(340.72)$ & $(140.23)$ & $(55.96)$ & $(110.53)$ \\
\hline \multirow[t]{2}{*}{ Lag of Human capital } & $0.713^{* * *}$ & & & & & & \\
\hline & $(6.11)$ & & & & & & \\
\hline \multirow[t]{2}{*}{ Lag of exports } & & $0.013^{*}$ & & & & & \\
\hline & & $(1.77)$ & & & & & \\
\hline \multirow[t]{2}{*}{ Lag of flows of FDI } & & & -0.000 & & & & \\
\hline & & & $(-1.16)$ & & & & \\
\hline \multirow[t]{2}{*}{ Lag of Investments } & & & & 0.001 & & & \\
\hline & & & & $(0.47)$ & & & \\
\hline \multirow[t]{2}{*}{ Lag of Imports } & & & & & $0.025^{* * *}$ & & \\
\hline & & & & & $(5.52)$ & & \\
\hline \multirow[t]{2}{*}{ Lag of stock of FDI } & & & & & & $0.004^{*}$ & \\
\hline & & & & & & $(1.67)$ & \\
\hline \multirow[t]{2}{*}{ Lag of R\&D } & & & & & & & $-0.025^{* * *}$ \\
\hline & & & & & & & $(-5.31)$ \\
\hline \multicolumn{8}{|c|}{$X_{i t}=$ Human capital } \\
\hline \multirow[t]{2}{*}{ Lag of TFP } & $-0.038^{*}$ & & & & & & \\
\hline & $(-1.68)$ & & & & & & \\
\hline \multirow[t]{2}{*}{ Lag of Human capital } & $0.838^{* * *}$ & & & & & & \\
\hline & $(11.85)$ & & & & & & \\
\hline \multicolumn{8}{|c|}{$X_{i t}=$ Export } \\
\hline \multirow[t]{2}{*}{ Lag of TFP } & & $-0.024^{* * *}$ & & & & & \\
\hline & & $(-3.52)$ & & & & & \\
\hline \multirow[t]{2}{*}{ Lag of exports } & & $0.981^{* * *}$ & & & & & \\
\hline & & $(221.75)$ & & & & & \\
\hline \multicolumn{8}{|c|}{$X_{i t}=\mathrm{FDI}$ flow } \\
\hline Lag of TFP & & & -0.982 & & & & \\
\hline & & & $(-0.25)$ & & & & \\
\hline Lag of flows of FDI & & & $0.777^{* * *}$ & & & & \\
\hline & & & $(7.92)$ & & & & \\
\hline & & & $X_{i t}=$ Invest & & & & \\
\hline Lag of TFP & & & & -0.003 & & & \\
\hline & & & & $(-0.49)$ & & & \\
\hline Lag of Investments & & & & $0.977^{* * *}$ & & & \\
\hline & & & & $(229.12)$ & & & \\
\hline & & & $X_{i t}=\operatorname{Imp}$ & & & & \\
\hline Lag of TFP & & & & & 0.036 & & \\
\hline & & & & & $(1.42)$ & & \\
\hline Lag of Imports & & & & & $0.926^{* * *}$ & & \\
\hline & & & & & $(24.16)$ & & \\
\hline & & & $X_{i t}=\mathrm{FDI} \mathrm{st}$ & & & & \\
\hline Lag of TFP & & & & & & -0.733 & \\
\hline & & & & & & $(-1.26)$ & \\
\hline Lag of stock of FDI & & & & & & -0.026 & \\
\hline & & & & & & $(-0.45)$ & \\
\hline & & & $X_{i t}=\mathrm{R} \&$ & & & & \\
\hline Lag of TFP & & & & & & & $-0.181^{*}$ \\
\hline & & & & & & & $(-1.68)$ \\
\hline Lag of R\&D & & & & & & & $0.680^{* * *}$ \\
\hline & & & & & & & $(7.49)$ \\
\hline $\mathrm{N}$ & 409 & 216 & 142 & 84 & 216 & 132 & 203 \\
\hline & & $\mathrm{p}$-value & the Grang & ausality test & & & \\
\hline$X_{i, t}$ to $T F P_{i, t}$ & $0.000^{* * *}$ & $0.077^{*}$ & 0.248 & 0.637 & $0.000^{* * *}$ & $0.096^{*}$ & $0.000^{* * *}$ \\
\hline$T F P_{i, t}$ to $X_{i, t}$ & $0.094^{*}$ & $0.000^{* * *}$ & 0.806 & 0.621 & 0.156 & 0.209 & $0.093^{*}$ \\
\hline
\end{tabular}

Note: $t$ statistics in parentheses, ${ }^{*},{ }^{* *},{ }^{* * *}$ denotes statistical significance at 10,5 , and $1 \%$ respectively. 
Figure 1: Impulse response functions from PVAR model - all EU countries

(a) Human Capital

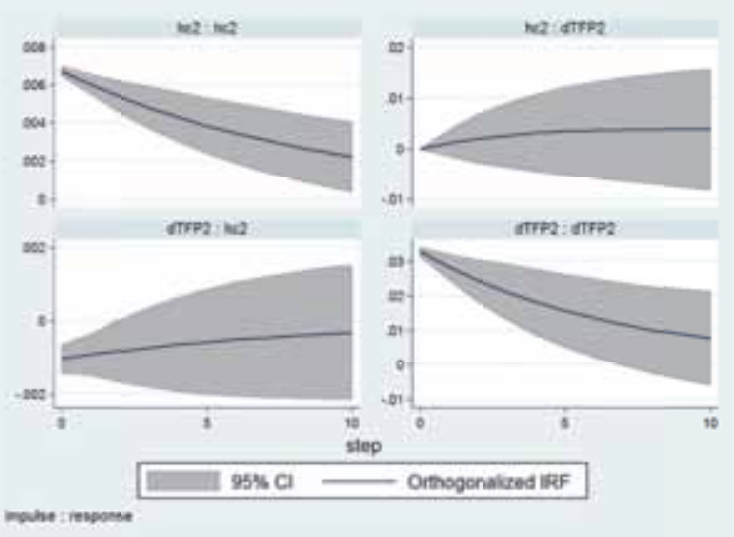

(c) FDI flow

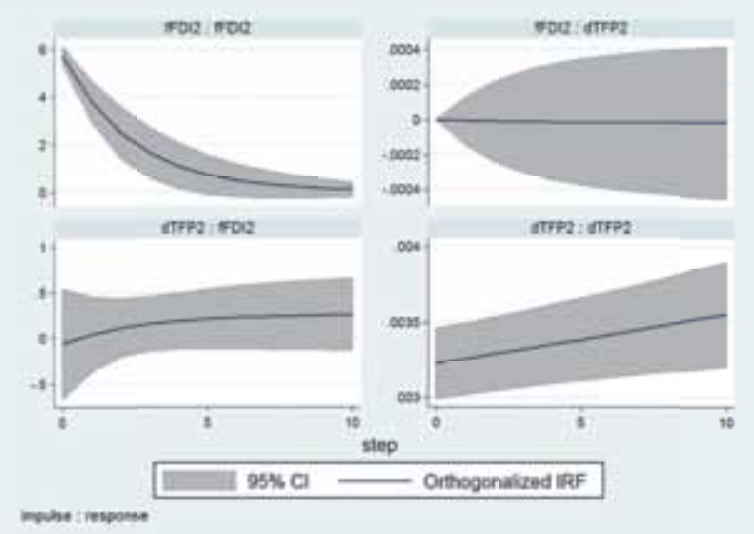

(e) Import

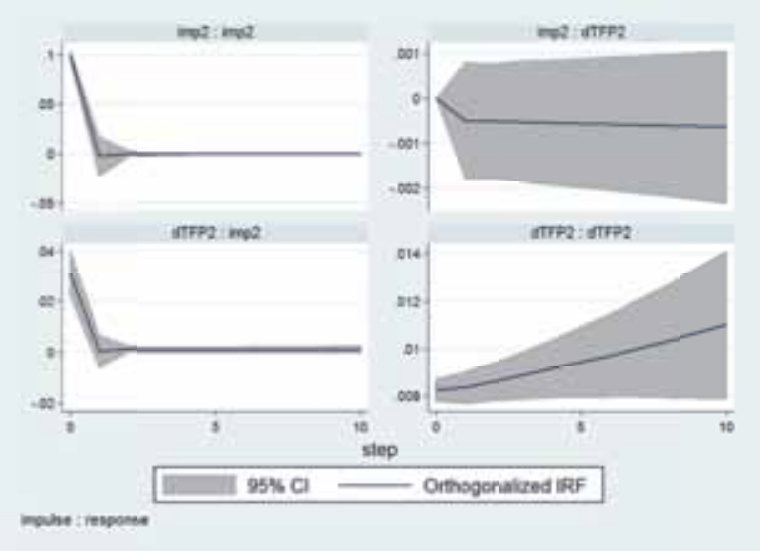

(g) $R \& D$

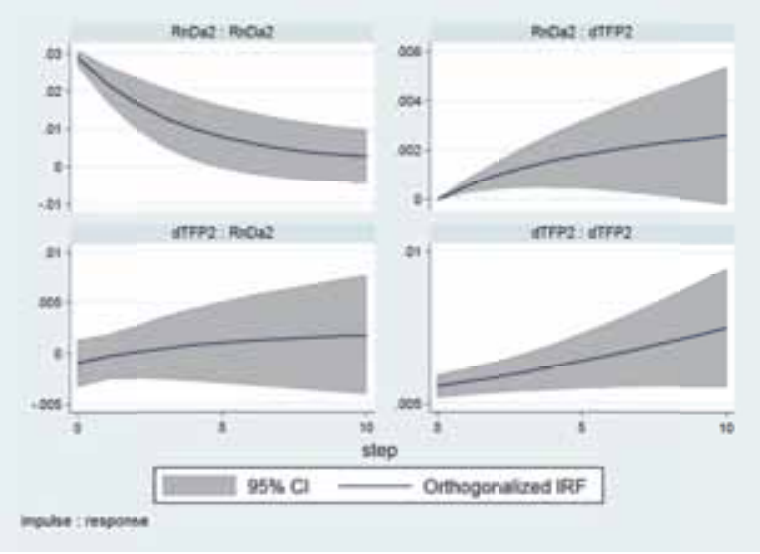

(b) Export

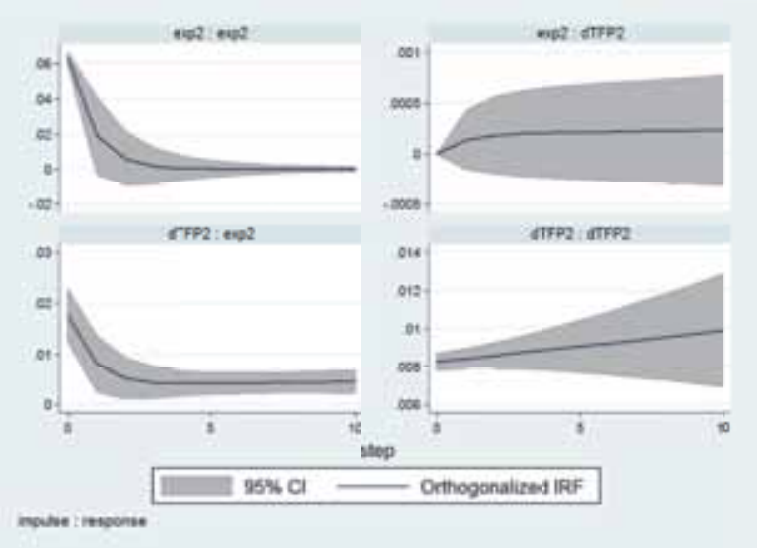

(d) GFCF (Investment)

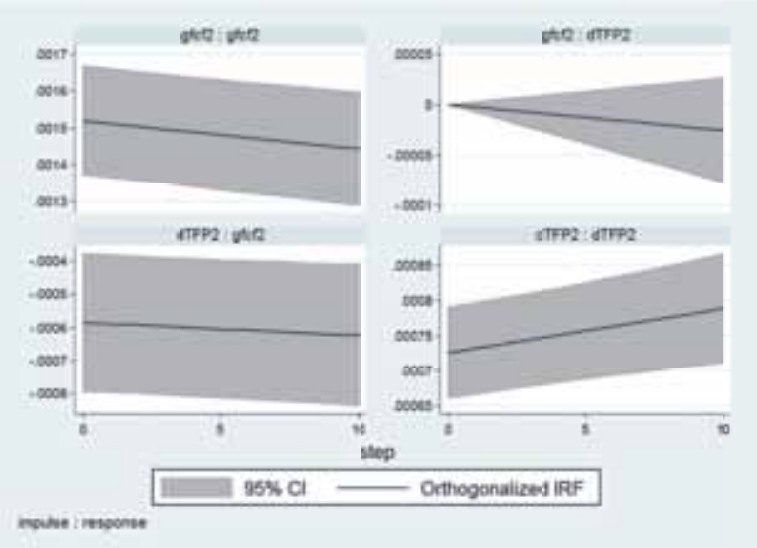

(f) FDI Stock

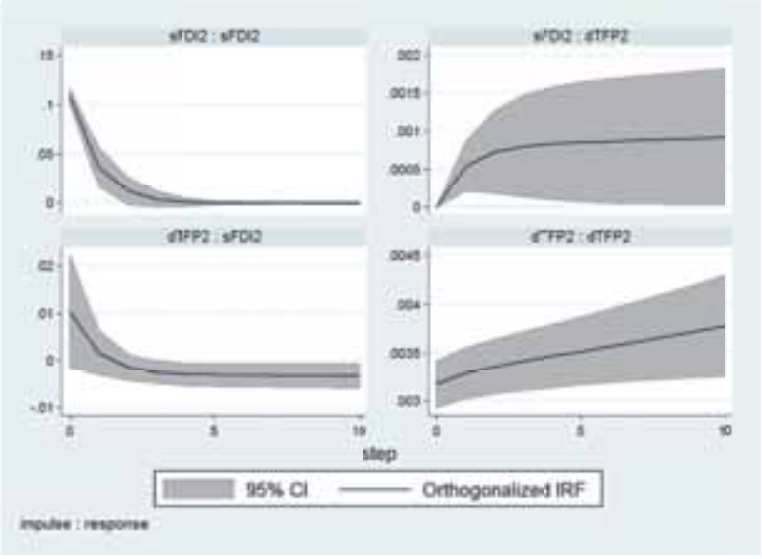


Figure 2: Impulse response functions from PVAR model - Core EU countries

(a) Human Capital

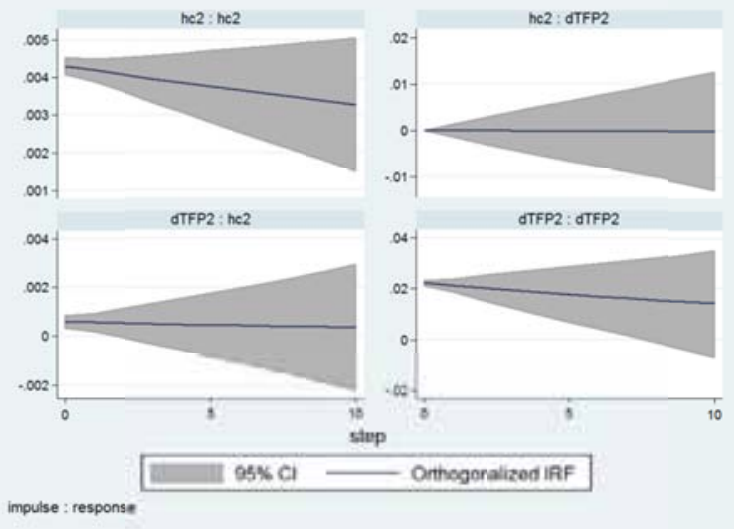

(c) FDI Flow

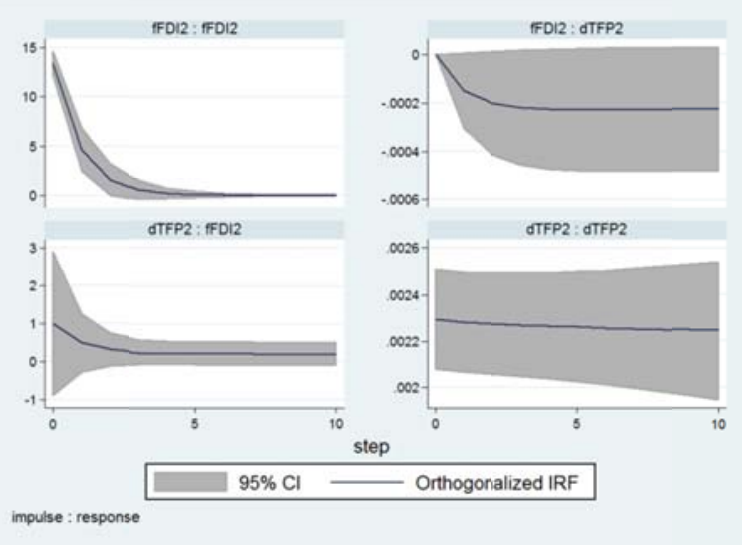

(e) Import

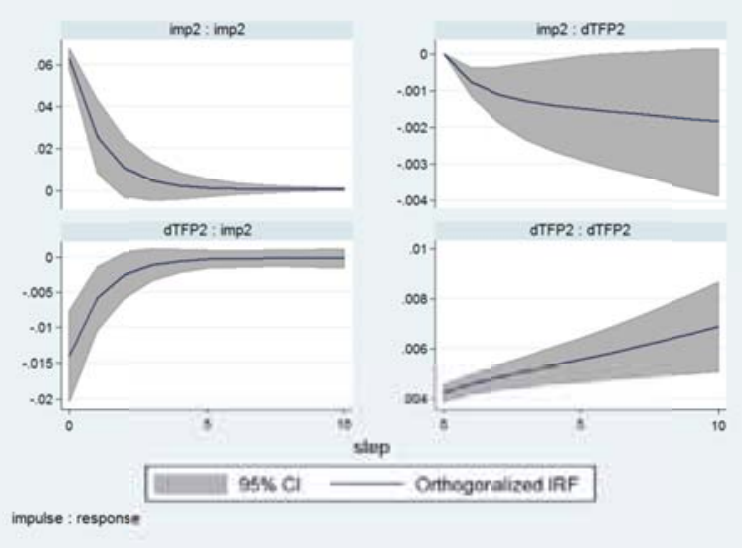

(g) $R \& D$
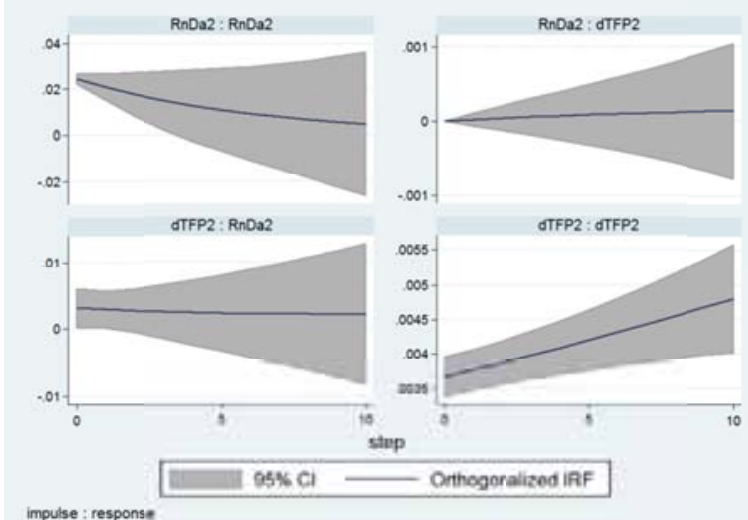

(b) Export

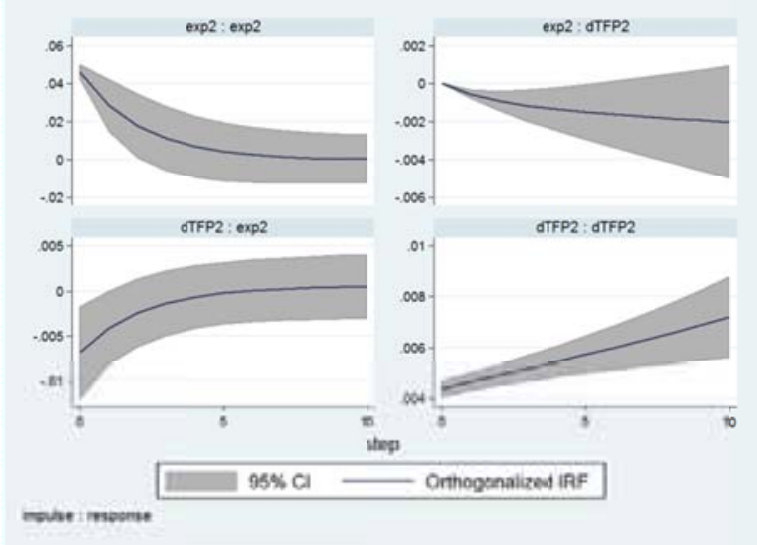

(d) GFCF (Investment)

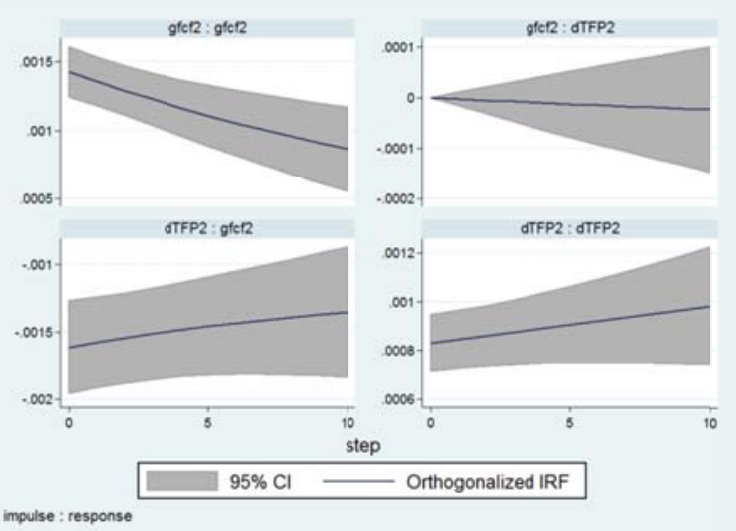

(f) FDI Stock

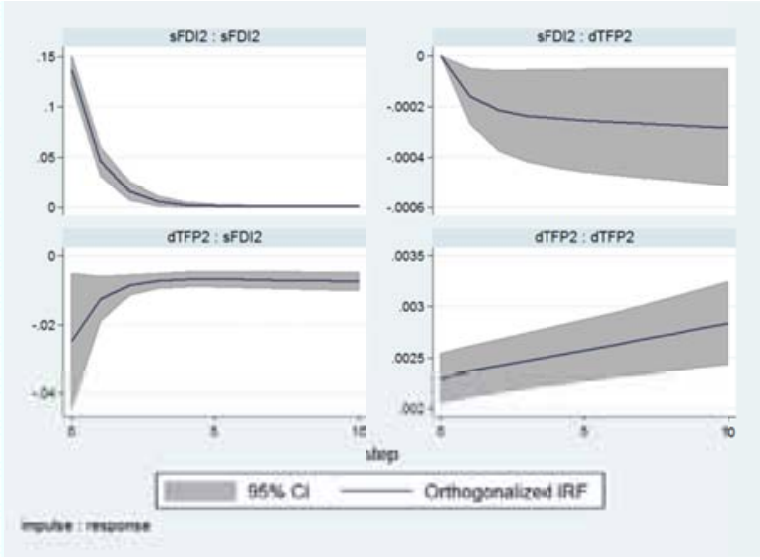


Figure 3: Impulse response functions from PVAR model - Periphery EU countries

(a) Human Capital

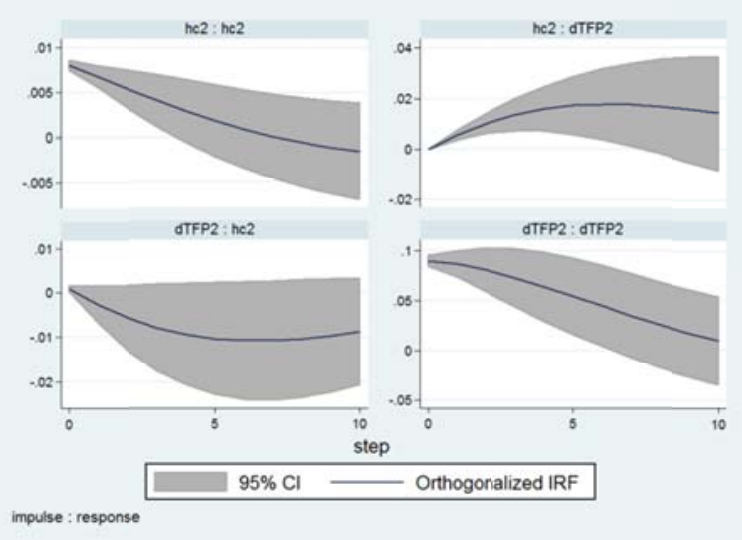

(c) FDI Flow

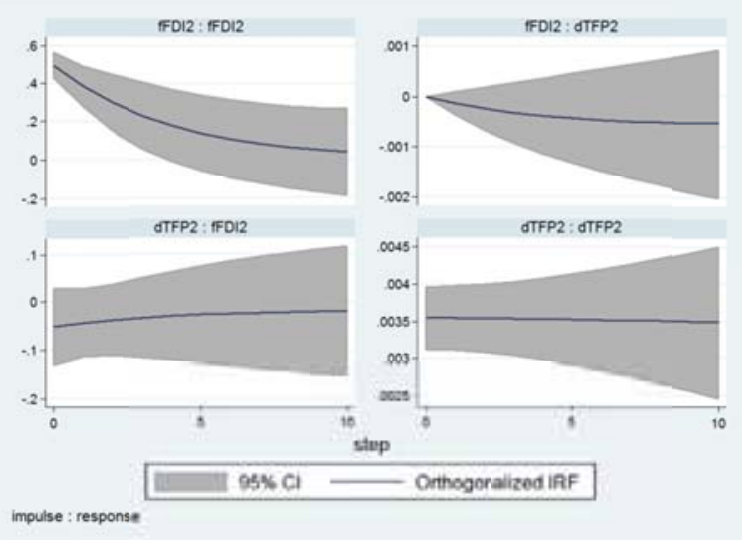

(e) Import

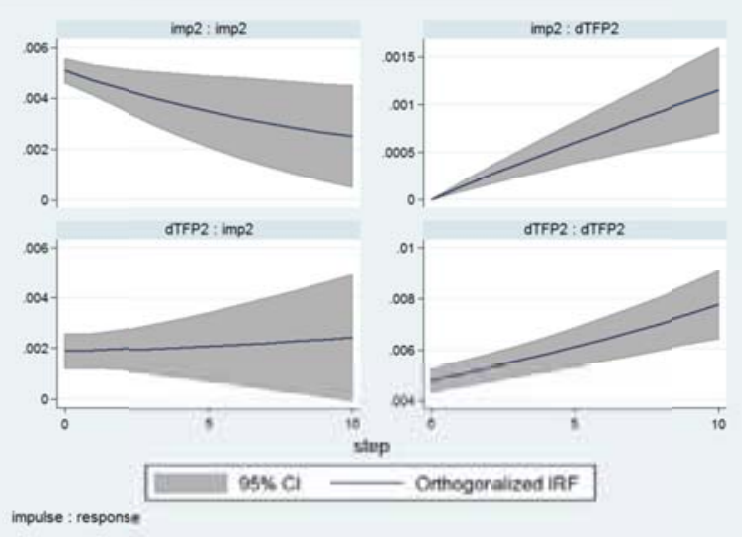

(g) $R \& D$

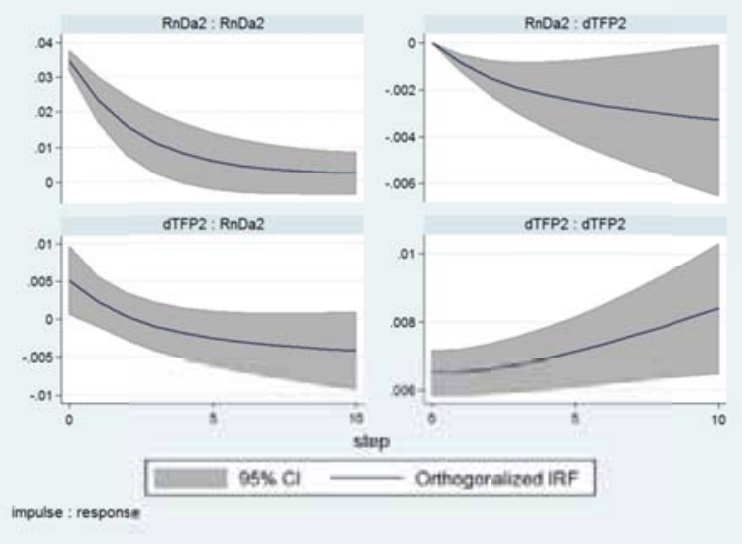

(b) Export

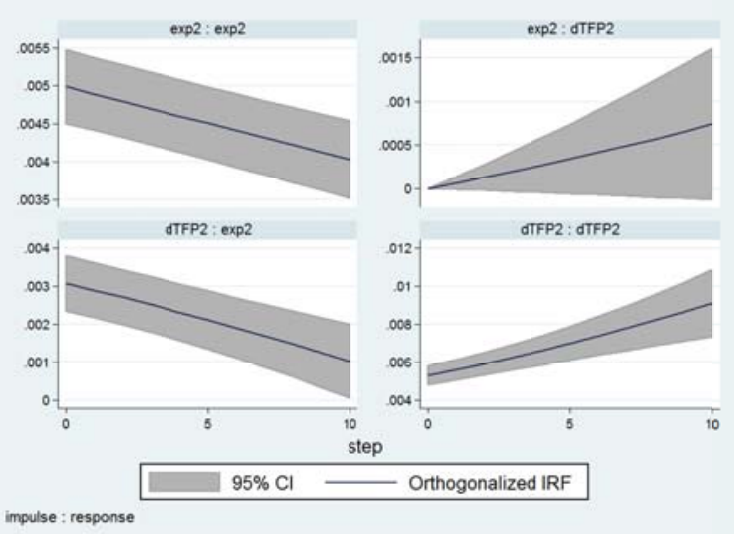

(d) GFCF (Investment)

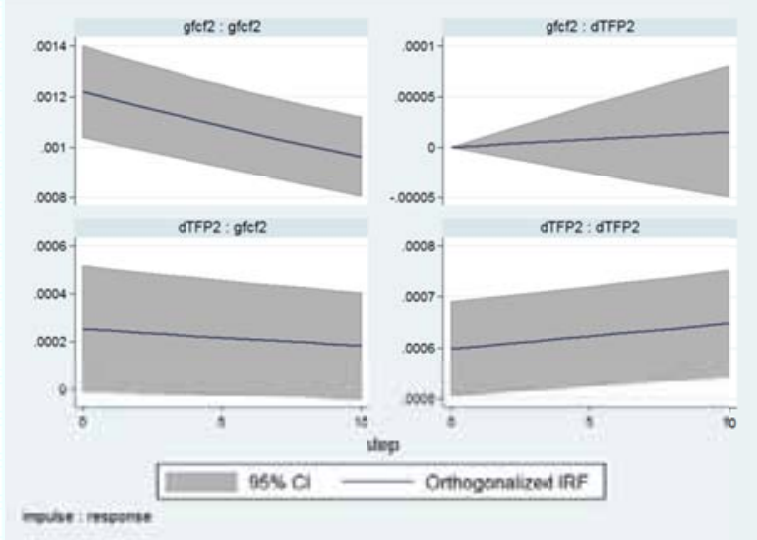

(f) FDI Stock

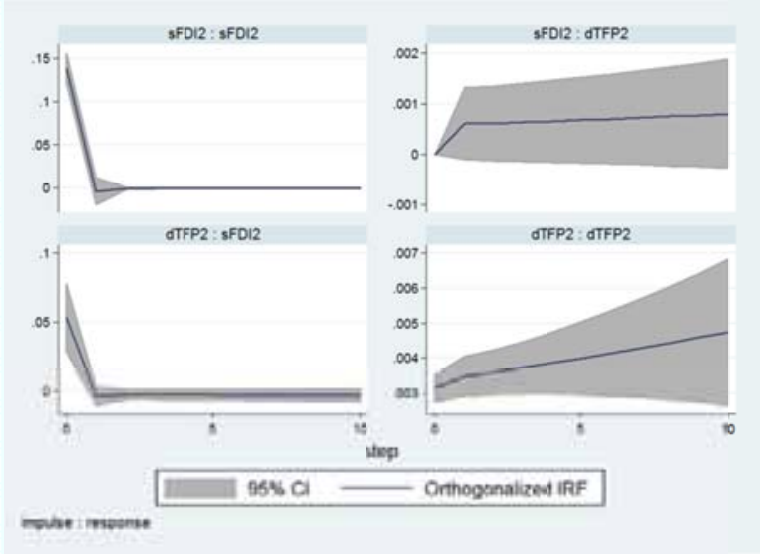


and statistically significant for Human capital and imports while the sign of $R \& D$ expenditure is opposite of what theory implies. It seems that imported goods from old EU members carry significant technological component for peripheral EU countires, in contrast to old members where tests show that trade doesn't serve the main role in the growth of productivity. Productivity growth in peripheral countries seems to be dependant on absorptive capacities as well, especially human capital. This result has implications for economic policies, in particular those supporting improvement in education and skills of the working contigent. Results also inform literature on determinants of economic growth in a wider group of peripheral EU countries, in particular new member states (see Martin and Winkler (2009), Kutan and Yigit (2009), Kočenda et al. (2006)) adding new evidence on the significance of trade in general, imports in particular, as well as absorption capacities for the reduction gap reduction with respect to $\mathrm{EU}$ as technological frontier.

Impulse response functions for all EU member countries are presented in the Figure 1 . The results are in line with results in Table 6. FDI stocks and R\&D expenditures have positive and statistically significant effect on the TFP that lasts more than 5 periods.

In the case of the Core group of countries (Figure 2), impulse response functions are in line with Table 7 results for Exports, Imports and FDI stocks, while FDI flows' IRF is statistically insignificant. On the other hand, effect of the first three variables on the TFP is significant, but negative (opposite to the theoretical expectation).

In the Periphery group of countries (Figure 3) impulse response functions indicate that impact of Human capital and imports are statistically significant and positive, while $R \& D$ expenditure is significant but of a wrong sign (compared to theory).

\section{CONCLUSION}

This paper examines the convergence of TFP within the European Union. Firstly, we employ a log $t$ test and data sets to endogenously estimate convergence clubs within the EU and Europe, and test for their significance and robustness. Our results indicate that there are two to four TFP convergence clubs in Europe and conclusion is sensitive to number of countries (non-EU vs. EU) included into analysis.

Secondly, we employ PVAR test in order to investigate channels of diffusion between European Countries. We find that the level of FDI stocks and R\&D expenditures are important channels of diffusion of technology on the EU-wide level. Within the periphery group of countries imports and human capital are major drivers of TFP growth. Obviously, Human capital as absorption constraint is an important factor of technology transfer in the periphery, while the importance of imports might be related to imports of capital goods, especially taken that one of stylized facts of transition was a huge current account deficit in accession countries which was strongly correlated with investment to savings ratios (not that much with budget deficits). On the other hand, when it comes to core countries the theory is not supported by facts. Four indicators have causal effect going into direction of TFP, but all estimated coefficients are of the "wrong sign" indicating more complex dynamics within the core countries.

Other than informing literature on technology transfer, our results have implications for economic policies as well, especially concerning pheriphery group of EU countries. This group of countries is a less developed convergence club withn EU, benefiting significantly from from trade with the rest of EU countires. Our results suggest that imports (capital goods) might be more important than exports as a channel of technology transfer for these countries. Therefore, policies that facilitate trade, especially on the import side (investment side) between old and peripheral EU countries, would have expected positive effect on perfipheral EU countries technological gap reduction and their respective economic growth. Furthermore, trade supporting policies of that sort would also be beneficial for reduction of inter EU development differences and support EU cohesion agenda. Since absorption capacities are shown to have imortant effect on technology transfer in peripheral EU countries, we see policies that improve local pool of knowledge, especially those that adress human capital, as highly beneficial for their economic growth and catching-up with old EU members. This result is also of importance for policy makers on the country level, i.e. lower than EU, because policies directed towards asorptive capacities fall within their domain.

The limitations of our analysis are related to the methodology and variable selection. Convergence tests in the literature have shown to be biased with respect to the implemented methodology so we report results as specific to our model design. Confirmation of convergence in our model implies stohastic convergence process rather than convergence to stationary state so results should be compared to empirical work on convergence based on time series estimators, much less then Barro regression approach. On the variable selection side, we point to the issue of construction and interpretability of TFP as a proxy for technological gap reduction. Furthermore, other variables 
also enter the empirical model as macroeconomic agregates and potentially contain omissions and biases, especially in view of evidence on spillover effects at industry and firm level in the literature. Future research would therefore benefit from more robustness tests, especially on the methodological side, but also include other proxies for technology and channels of technology transfer. We believe it would be useful to extend the model with more variables, especially on the side of absoption capacities.

\section{REFERENCES}

Abrigo, M. R. and Love, I. 2016. Estimation of panel vector autoregression in Stata: a package of programs. Stata Journal 16 (3): 778-804.

Acemoglu D. and Zilibotti F. 1999. Information accumulation in development. Journal of Economic Growth 4 (1): 5-38.

Alfaro, L., Chanda, A., Kalemli-Ozcan, S., and Sayek, S. 2004. FDI and economic growth: the role of local financial markets. Journal of International Economics 64 (1): 89-112.

Aw, B. Y., Chung, S. and Roberts, M. J. 2000. Productivity and turnover in the export market: Micro-level evidence from the Republic of Korea and Taiwan (China). The World Bank Economic Review 14 (1): 65-90.

Barba Navaretti, G. and Venables, A. 2006. Multinational firms in the world economy. Princeton, NJ: Princeton University Press.

Benhabib, J. and Spiegel, M. M. 1994. The role of human capital in economic development: Evidence from aggregate cross-country data. Journal of Monetary Economics 34 (2): 143-174

Bernard, A., Jensen, J., Redding, S., and Schott, P. 2007. Firms in international trade. Journal of Economic Perspectives 21 (3): 105-130.

Blalock, G. and Gertler, P. J. 2008. Welfare gains from foreign direct investment through technology transfer to cocal suppliers. Journal of International Economics 74 (2): 402-421.

Blomstrom, M. and Kokko, A. 1994. Home country effects of foreign direct investment: Evidence from Sweden. NBER Working Papers 4639.

Blomstrom, M. and Kokko, A. 1998. Multinational corporations and spillovers. Journal of Economic Surveys 12 (3): 247-77.

Borensztein, E., De Gregorio, J., and Lee, J.-W. 1998. How does foreign direct investment affect economic growth? Journal of International Economics, 45 (1): 115-135.

Bruegel Pack, H. and Saggi, K. 2001. Vertical technology transfer via international outsourcing. Journal of Development Economics 65 (2): 389-415.

Coe, D. and Helpman, E. 1995. International R\&D spillovers. European Economic Review 39 (5): 859-887.
Coe, D., Helpman, E. and Hoffmaister, A. W. 2009. International R\&D spillovers and institutions. European Economic Review 53 (7): 723-741.

Coe, D., Helpman, E., and Hoffmaister, A. 1997. North-South R\&D spillovers. Economic Journal 107 (440): 134-49.

Comin, D. and Hobijn, B. 2004. Cross-country technology adoption: making the theories face the facts. Journal of Monetary Economics 51 (1): 39-83.

Crespo Cuaresma, J., Scharler, J., and Nationalbank, O. 2004. On the determinants of absorptive capacity: Evidence from OECD Countries. Proceedings of OeNB Workshops: Workshop No. 02.

Damijan, J.P., Polanec, S., and Prasnikar, J. 2004. Selfselection, export market heterogeneity and productivity improvements: Firm level evidence from Slovenia. LICOS Discussion Papers: Discussion Paper 148/2004.

De Loecker, J. 2007. Do exports generate higher productivity? Evidence from Slovenia. Journal of International Economics 73 (1): 69-98.

Falvey, R. E., Foster, N. and Greenaway, D. 2002. North-South trade, knowledge spillovers and growth. Journal of Economic Integration 17 (4): 650-670.

Falvey, R., Foster, N. and Greenaway, D. 2004. Imports, exports, knowledge spillovers and growth. Economics Letters 85 (2): 209-213.

Feenstra, R. C., Inklaar, R., and Timmer, M. P. 2015. The next generation of the Penn World Table. American Economic Review 105 (10): 3150-3182.

Findlay, R. 1978. Relative backwardness, direct foreign investment, and the transfer of technology: A simple dynamic model. The Quarterly Journal of Economics 92 (1): $1-16$.

Fryges, H. and Wagner, J. 2007. Exports and oroductivity growth first evidence from a continuous treatment approach. Review of World Economics 144 (4): 695-722.

Funk, M. 2001. Trade and international R\&D spillovers among OECD countries. Southern Economic Journal 67 (3): 725-736.

Girma, S. and Görg, H. 2007. The role of the efficiency gap for spillovers from FDI: Evidence from the UK electronics and engineering sectors. Open Economies Review 18 (2): 215-232.

Girma, S., Greenaway, S. D., and Kneller, R. 2003. Export market exit and performance dynamics: A causality analysis of matched firms. Economics Letters 80 (2): 181-187.

Girma, S., Greenaway, S. D., and Kneller, R. 2004. Does exporting increase productivity? A microeconometric analysis of matched firms. Review of International Economics 12 (5): 855-866.

Globerman, S., Kokko, A., and Sjholm, F. 2000. International technology diffusion: evi-dence from Swedish patent data. Kyklos 53 (1): 17-38. 
Gonalves, D. 2015. GETDATA: Stata module to import SDMX data from several providers. Boston College Department of Economics: Statistical Software Components S458093.

Görg, H. and Greenaway, D. 2004. Much ado about nothing? Do domestic firms really benefit from foreign direct investment? World Bank Research Observer 19 (2): 171-197.

Greenaway, D. and Kneller, R. 2007. Industry differences in the effect of export market entry: Learning by exporting? Review of World Economics 143 (3): 416-432.

Griffith, R., Redding, S., and Simpson, H. 2004. Foreign ownership and productivity: New evidence from the service sector and the R\&D lab. Oxford Review of Economic Policy 20 (3): 440-456.

Grossmanand, G. M. and Helpman, E. 1992. Innovation and growth in the global economy. Cambridge, MA: The MIT press.

Hall, R. E. and Jones, C. 1999. Why do some countries produce so much more output per worker than others? The Quarterly Journal of Economics, 114 (1): 83-116.

Halpern, L., Koren, M., and Szeidl, A. 2011. Imported inputs and productivity. The American Economic Review 105 (12): 3660-3703

Harris, R. 2009. Spillover and backward linkage effects of FDI: Empirical evidence for the UK. Spatial Economics Research Centre, London: SERC Discussion Papers 0016.

Harris, R. and Robinson, C. 2003. Foreign ownership and productivity in the United King-dom estimates for U.K. manufacturing using the ARD. Review of Industrial Organization 22 (3): 207-223.

Harris, R.D. 2002. Foreign ownership and productivity in the United Kingdom - Some issues when using the ARD stablishment level data. Scottish Journal of Political Economy 49 (3): 318-335.

Harrison, A. E. and Aitken, B. J. 1999. Do domestic firms benefit from direct foreign investment? Evidence from Venezuela. American Economic Review 89 (3): 605-618.

Haskel, J., Pereira, S. C., and Slaughter, M. J. 2007. Does inward foreign direct invest-ment boost the productivity of domestic firms? The Review of Economics and Statistics 89 (3): 482-496.

Havranek, T. and Irsova, Z. 2010. Meta-analysis of intra-industry FDI spillovers: Updated evidence. Czech Journal of Economics and Finance 60 (2): 151-174.

Holtz-Eakin, D., Newey, W., and Rosen, H.S. 1988. Estimating vector auto regressions with panel data. Econometrica 56 (6): 1371-1395.

Isaksson, A. 2001. The importance of human capital for the trade-growth link. Statistics and Information Networks Branch of UNIDO: Working Paper No 2.

Isgut, A. 2001. What's different about exporters? Evidence from Colombian manufacturing. Journal of Development Studies 37 (5): 57-82.
Javorcik, B. and Spatareanu, M. 2008. To share or not to share: Does local participation matter for spillovers from foreign direct investment? Journal of Development Economics 85 (1-2): 194-217.

Javorcik, B. S. 2004. Does foreign direct investment increase the productivity of domestic firms? In search of spillovers through backward linkages. American Economic Review 94 (3): 605-627.

Kao, C., Chiang, M.-H., and Chen, B. 1999. International R\&D spillovers: An application of estimation and inference in panel cointegration. Oxford Bulletin of Economics and Statistics 61 (0): 691-709.

Keller, W. 2000. Do trade patterns and technology flows affect productivity growth? World Bank Economic Review 14 (1): 17-47.

Keller, W. 2004. International technology diffusion. Journal of Economic Literature 42 (3): 752-782.

Keller, W. 2009. International trade, foreign direct investment, and technology spillovers. Handbook of the Economics of Innovation 2: 793-829.

Keller, W. and Yeaple, S. 2009. Multinational enterprises, international trade, and produc-tivity growth: Firmlevel evidence from the United States. The Review of Economics and Statistics 91 (4): 821-831.

Kočenda, E., Kutan, A. M. and Yigit, T. M. 2006. Pilgrims to the Eurozone: How far, how fast? Economic Systems 30 (4): 311-327.

Kutan, A. M. and Yigit, T. M. 2009. European integration, productivity growth and real convergence: Evidence from the New Member States. Economic Systems 33 (2): 127-137.

Markusen, J. and Venables, A. 1999. Foreign direct investment as a catalyst for industrial development. European Economic Review 43 (2): 335-356.

Martin, R. and Winkler, A. 2009. Real convergence in Central, Eastern and South-Eastern Europe. UK, London: Palgrave Macmillan.

Mayer, J. 2001. Technology diffusion, human capital and economic growth in developing countries. United Nations Conference on Trade and Development: Discussion Papers No.154.

Melitz, M. J. 2003. The impact of trade on intra-industry real locations and aggregate industry productivity. Econometrica 71 (6): 1695-1725.

Merikll, J., Poltimae, H., and Paas, T. 2013. International technology diffusion. Eastern European Economics 51 (2): 21-38.

Nelson, R. R. and Phelps, E. S. 1966. Investment in humans, technological diffusion, and economic growth. The American Economic Review 56 (2): 69-75.

Nicolini, M. and Resmini, L. 2010. FDI spillovers in New EU Eember States. The Economics of Transition 18 (3): 487-511. 
Ottaviano, G. and Mayer, T. 2008. The happy few: The internationalisation of European firms. Intereconomics 43 (3): 135-148.

Parente, S. L. and Prescott, E. C. 2005. A unified theory of the evolution of international income levels. Handbook of Economic Growth 1 (B): 1371-1416.

Phillips, P. and Sul, D. 2007. Transition modeling and econometric convergence tests. Econometrica 75 (6): 1771-1855.

Renard, M. F., ed. 2002. China and its regions. Cheltenham, UK: Edward Elgar Publishing.

Sjholm, F. 1996. International transfer of knowledge: The role of international trade and geographic proximity. Review of World Economics 132 (1): 97-115.

Wagner, J. 2007. Exportsand productivity: A survey of the evidence from firm-level Data. The World Economy 30 (1): 60-82.
Wooster, R. and Diebel, D. S. 2010. Productivity spillovers from foreign direct investment in developing countries: A meta-regression analysis. Review of Development Economics 14 (s1): 640-655.

Xu, B. 2000. Trade, FDI, and international technology diffusion. Journal of Economic Integration 15: 585-601.

Xu, B. and Wang, J. 1999. Capital goods trade and R\&D spillovers in the OECD. Canadian Journal of Economics 32 (5): 1258-1274.

Yasar, M. and Morrison Paul, C. J. 2007. International linkages and productivity at theplant level: Foreign direct investment, exports, imports and licensing. Journal of International Economics 71 (2): 373-388. 